\title{
ANALISIS PRODUCTS PLACEMENT SEBAGAI PENDUKUNG UNSUR NARATIF FILM “TRANSPORTER 3”
}

\author{
Hanifah Istiqomah \\ Siti Maemunah \\ Agnes Karina Pritha Atmani \\ Jurusan Film \& Televisi, Fakultas Seni Media Rekam, Institut Seni Indonesia Yogyakarta \\ Jl. Parangtritis km. 6.5 Yogyakarta Telp. (0274) 381047
}

\begin{abstract}
ABSTRAK
Film "Transporter 3" menarik untuk diteliti karena terdapat satu merek produk muncul secara menonjol dari awal sampai akhir cerita sebagai properti. Kemunculan merek produkproduk dalam film mempunyai fungsi sebagai pendukung unsur naratif dari cerita, meskipun tidak semua. Penelitian ini bertujuan untuk mengetahui kehadiran dan peran products placement dalam film dan juga menjabarkannya sebagai pendukung unsur naratif film. Metode penelitian menggunakan kualitatif dengan pendekatan deskriptif dengan fokus terhadap adegan yang menampilkan products placement. Pembahasan dalam penelitian ini adalah fungsi products placement sebagai pendukung unsur naratif film "Transporter 3". Teknik pengambilan data dilakukan dengan cara dokumentasi dan observasi secara langsung pada karya film. Data penelitian diolah dan dianalisis menggunakan teori-teori tentang products placement oleh Cristel Antonia Russel, Rosemary Avery dan Rosellina Ferraro, serta tentang naratif film oleh Himawan Pratista dan David Broadwell. Bedasarkan hasil analisis kesimpulannya adalah products placement dalam film "Transporter3" muncul melalui 36 scene. Kemunculan products placement lebih banyak menggunakan dimensi visual dari pada dimensi auditory. Akibat adanya products placement dalam film "Transporter 3" sebagian besar dapat mendukung kehadiran unsur naratif seperti plot, tokoh, konflik dan latar. Kehadiran products placement dalam "Transporter 3" paling mendukung unsur konflik, kemudian tokoh dan plot serta paling akhir adalah latar.
\end{abstract}

Kata Kunci: Naratif, Product Placement, Produk

\section{Pendahuluan}

Pesatnya perkembangan film seiring dengan ketatnya persaingan bisnis dalam memperkenalkan produk (iklan). Kesempatan memperkenalkan produk tidak dibiarkan begitu saja oleh produsen-produsen untuk membuat media iklan yang menarik mulai dari menjadi sponsor hingga endorsement. Awalnya para produsen hanya sebagai sponsor diciptakannya karya film, namun semakin berkembangnya film dan kebutuhan pemasaran mereka meningkat, saat ini sering sekali kita jumpai produk merek terkenal maupun kurang terkenal muncul dalam beberapa adegan film.

Produsen dituntut memperkenalkan produknya melalui strategi jitu, menarik dan mengena kepada masyarakat. Industri film dituntut menyajikan cerita menarik, disamping adanya perkembangan teknologi. Kedua tuntutan sangat berkaitan oleh pendanaan sponsor dari para produsen kepada industri film. Karya idealis film pada masa sekarang memang berhubungan dengan 
pertimbangan komersial untuk mendapatkan keuntungan dan minat masyarakat. Dari sisi produsen sendiri, dalam masa sekarang ini sangat sulit jika mengandalkan iklan dari televisi saja. Berbagai strategi promosi, product placement dalam film adalah salah satu cara promosi produk yang menarik dan langsung mengena kepada masyarakat. Penggunaan product placement sendiri mulai berkembang pesat pada era 1980-an di sebuah film Hollywood "The ExtraTerrestrial” (1982). Beberapa penggunaan product placement menjadi kendala dalam industri film, karena tidak mudah menempatkan produk untuk muncul dalam sebuah teks film.

Meskipun begitu industri film juga tidak kalah kreatif untuk menggunakan product placement tanpa menampilkan dengan begitu mencolok di mata penonton melalui berbagai strategi penyajian. Salah satu tekniknya yaitu dengan mencampurkan bersama naratif dari film secara keseluruhan karena akan berkaitan dalam alur cerita dan bisa menjadi cara paling efektif penggunaan product placement. Naratif dalam film merupakan unsur utama selain unsur sinematik, keduanya saling berinteraksi dan berkesinambungan untuk membentuk film. Unsur naratif berhubungan dengan aspek cerita atau tema sedangkan unsur sinematik merupakan aspek teknis dalam produksi sebuah film. Naratif adalah suatu rangkaian peristiwa saling berhubungan satu sama lain dan terikat oleh logika sebab akibat (kausalitas) yang terjadi dalam satu ruang dan waktu (Pratista, 2008: 33).

Film-film dengan product placement bisa dilihat diantaranya dalam film populer James Bond, "Golden Eye", "Quantum of Slace" dan juga film "Transporter" mulai dari sekuel 1 sampai dengan 3. Film Transporter 1 dan 2 sudah muncul product placement dari beberapa macam produk. Film "Transporter 3" menampilkan dengan jelas product placement dengan merek terkenal seperti handphone Nokia, mobil Audi , mobil Mercedes-Benz dan juga minuman vodka Seagram's. Keunikan film "Transporter 3" adalah selama cerita menggunakan salah satu produk mobil yaitu Audi sebagai properti dalam setiap scene tokoh utama. Mobil Audi yang dimaksud merupakan mobil milik tokoh utama dan derkaitan dengan cerita film dari awal hingga akhir cerita.

Film "Transporter 3" dirilis pada 17 Desember 2009, disutradarai oleh sutradara kompeten papan atas Olivier Megathon, dibintangi oleh aktor laga senior Jason Statham dan mendapat rating bagus di IMDb yaitu 6.1/10. IMDb adalah sumber informasi resmi dan populer di dunia untuk konten dan rating film. Film "Transporter 3" berhasil meraih penghargaan Best International Movie di Rusia dalam ajang penghargaan bergengsi MTV Movie Awards tahun 2009. Sutradara Oliver Megathon mendapat 
penghargaan juga melalui film ini di ajang European Film Awards di tahun yang sama.

Pembahasan inti dari penelitian tentang product placement sebagai pendukung unsur naratif dalam film seperti plot, tokoh, konflik dan latar. Kemunculan dari product placement akan dibahas lanjut mengenai bagaimana eksistensi dimensi, yaitu visual atau auditory dan juga bagaimana product placement menjadi pendukung terhadap unsur naratif. Penelitian ini bersudut pandang dari estetika film khususnya unsur naratif dalam membahas adegan product placement pada film "Transporter 3".

Beberapa fakta di atas dapat menjadi landasan untuk membuat penelitian mengenai product placement dalam film “Transporter 3" sebagai pendukung unsur naratif. Penelitian ini bertujuan untuk mengetahui kehadiran dan peran products placement dalam film dan juga menjabarkannya sebagai pendukung unsur naratif film.

\section{Naratif}

Menurut Pratista (2008: 33), naratif adalah suatu rangkaian peristiwa yang berhubungan satu sama lain dan terikat oleh logika sebab akibat (kausalitas) yang terjadi dalam satu ruang dan waktu. Setiap cerita apapun bentuknya dan seberapa pendeknya pasti mengandung unsur naratif. Unsur naratif merupakan dasar dalam pembentukan cerita, tanpa adanya unsur ini cerita akan sulit. Unsur-unsur naratif berhubungan dengan aspek cerita atau tema film. Setiap film cerita tidak mungkin lepas dari unsur naratif. Setiap ceria pasti memiliki unsurunsur seperti tokoh, masalah, konflik, lokasi, waktu serta lainnya (Pratista, 2008: 2).

"Narration is the moment by moment process that guide us in building the story out of the plot. many factor enter into narration, but the most important ones for our purpose involve the range and the depth of story information that the plot presents" (Bordwell, 2003: 88).

Dari dua teori diatas, penelitian ini nantinya akan menggunakan kombinasi unsur-unsur naratif meliputi alur/plot (dari Bordwell), karakter/tokoh, konflik dan latar (khusus tempat).

a. Alur/plot

Alur adalah rangkaian peristiwa yang dijalin berdasarkan hukum sebab-akibat, dan merupakan pola yang berkaitan dengan peristiwa yang menggerakan jalannya cerita ke arah pertikaian dan penyelesaian (Riris, 1997: 14-15). Plot adalah apa yang ditampilkan secara eksplisit dalam sebuah teks. Plot urutan peristiwa bisa dibolak-balik (Eriyanto, 2013: 16).

\section{b. Karakter/tokoh}

Karakter merupakan unsur yang sangat penting dalam sebuah naratif film sebab mereka adalah salah satu unsur yang membantu penonton menangkap maksud dari isi film. Tanpa karakter tidak mungkin terjadi cerita dengan adanya peristiwa 
serta konflik. Oleh karena itu tidak pernah ada cerita film yang tidak melibatkan pemeran. Tokoh atau karakter merupakan unsur paling aktif yang menjadi penggerak cerita. Tokoh mempunyai watak, kepribadian dan sifat-sifat karakteristik tiga dimensional (Harymawan, 1988:25)

Didalam narasi (cerita) terdapat karakter, yakni orang atau tokoh yang mempunyai sifat atau perilaku tertentu. Karakter-karakter tersebut masing-masing mempunyai fungsi dalam narasi, sehingga narasi menjadi menyatu. Narasi tidak hanya menggambarkan isi, tetapi juga didalamnya terdapat karakterkarakter. Dengan adanya karakter, akan memudahkan bagi pembuat cerita dalam mengungkapkan gagasannya (Eriyanto, 2013: 65).

c. Konflik

Sebuah cerita pasti memiliki sebuah konflik yang diceritakan sepanjang penuturan film tersebut. Adanya konflik mampu membuat sebuah cerita dalam film lebih menarik. Konflik dapat mengikat perhatian penonton, memberikan emosi dan merangsang daya oikir penonton. Konflik adalah permasalahan yang kita ciptakan untuk menghasilkan pertentangan dalam sebuah keadaan sehingga menimbulkan dramatik yang menarik. Konflik biasanya timbul jika seorang tokoh tidak berhasil mencapai apa yang diinginkannya (Lutters, 2010: 100).

Konflik adalah dasar sari drama, karena konflik akan terjadi ketika dua karakter memiliki tujuan yang saling bertentangan pada waktu yang sama. Karaktar yang satu akan menang dan lainnya akan kalah (Seger, 1987: 125). Konflik-konflik yang terjadi sepanjang cerita bisa berfungsi sebagai konflik utama atau sub-konflik. Tiap sub-konflik harus bersifat mendukung karena bisa juga disebut sebagai konflik pendukung dan mempertegas kehadiran atau eksistensi konflik utama. Konflik utama inilah yang merupakan inti plot, inti struktur cerita dan sekaligus merupakan pusat pengembangan plot yang bersangkutan (Biran, 2006: 125126).

Unsur naratif paling penting selain tokoh adalah konflik. Tokoh dan konflik tidak bisa dipisahkan karena keduanya saling berhubungan. Konflik tidak akan terjadi jika tidak dibawakan oleh tokoh, konflik dapat digunakan untuk menunjukkan permainan kekuatan, ketidaksetujuan, perbedaan sudut pandang, perbedaan 
sikap dan filosofi. Meskipun hanya ada satu konflik yang menjadi inti cerita dari awal sampai akhir, tetapi kemunculan konflik-konflik kecil di setiap adegan akan memberi ketertarikan, pukulan dan dimensional pada sebuah cerita (Seger, 1987: 140).

d. Latar

Latar adalah salah satu hal utama yang mendukung unsur naratif. Latar juga mendukung dan menguatkan tindakan-tindakan tokoh dalam cerita. Fungsi utama latar adalah sebagai penunjuk ruang dan waktu untuk memberikan informasi. Selain itu, berfungsi juga secagai latar cerita yang mampu membangun mood sesuai tuntutan tema cerita. Latar tempat atau daerah terjadinya sebuah peristiwa dalam cerita. Sangat mungkin latar tempat sebuah teks prosa terdapat didalam ruang lingkungan. Di jalanan atau di sebuah kota misalnya (Nurgiyantoro 2002: 227). Peristiwa dalam drama adalah peristiwa fiktif yang menjadi hasil rekaan penulis (David Groote 1997, dalam Santosa 2008).

\section{Product Placement}

Product placement adalah kegiatankegiatan penempatan nama merek, produk, kemasan produk, lambang atau logo tertentu dalam sebuah film, acara televisi, ataupun media bergerak lain untuk mengingatkan audiens akan merek tersebut, sekaligus merangsang terciptanya pembelian (Avery and Ferraro, 2000: 217).

Ada tiga dimensi utama yang digunakan dalam penerapan product placement. Namun dalam penelitian ini hanya akan menggunakan dua dimensi yang membangun yaitu visual dan auditory. Berikut pengertian kedua dimensi Russell (1998):

a. Dimensi Visual

Dimensi Visual biasa disebut juga Screen Placement, yaitu saat produk atau jasa bermerek muncul di latar belakang seperti penempatan properti on-set atau iklan luar dijalanan. Screen Placement tergantung dari seberapa sering kemunculan untuk merek tersebut, dan bagaimana cara menyorot produk bermerek tersebut.

b. Dimensi Auditory

Dimensi Auditory sering disebut juga Script Placement, yaitu saat merek atau kegunaan produk tersebut disebutkan dengan tingkatan yang berbeda-beda, tergantung dari tekanan, ekspresi saat mengucapkan dan siapa yang menyebutkan merek tersebut.

\section{Pembahasan}

Tahap pertama adalah menentukan scene yang memunculkan product placement dalam film "Transporter 3". Tolak ukur penentuan kemunculan product placement adalah ketika nama merek, produk, kemasan 
produk, lambang atau logo tertentu muncul dalam sebuah film. Muncul disini bisa berupa aspek visual menampakan kasat mata dalam frame dan juga berupa audio yang terdengar oleh telinga bagi penonton.

Tahap kedua adalah membagi per-scene sesuai dimensi product placement. Tolak ukur pembagian dimensi visual yaitu saat produk atau jasa bermerek muncul di latar belakang seperti penempatan properti on-set atau iklan luar di jalan. Dimensi audio yaitu saat merek atau kegunaan/keunggulan produk tersebut disebutkan dengan tingkatan berbeda-beda, tergantung dari tekanan, ekspresi saat mengucapkan dan siapa yang menyebutkan merek tersebut.

Tahap ketiga menganalisis per produk dalam muncul film untuk mengetahui fungsi pendukung unsur naratif. Pembahasan unsur naratif dalam penelitian diantaranya plot, tokoh, konflik dan latar. Penjelasan akan dideskripsikan bersama kesimpulan per pembahasan produk, unsur-unsur lain akan dimasukkan ke dalam tabel. Tabel tersebut memiliki 4 kolom yaitu scene, produk, unsur naratif (plot, tokoh, konflik dan latar).
Kolom scene menjelaskan nomor, keterangan dan screenshot gambar pada scene yang dimaksud sesuai banyaknya jumlah shot. Pada kolom produk akan diisi dengan merek produk disertai logo atau contoh kemasan dalam frame. Kolom ketiga diisi oleh unsur-unsur naratif yang mempresentasikan product placement dalam setiap scene kolom pertama. Selanjutnya kolom terakhir yaitu keterangan, berisi tentang deskripsi scene dan kaitan product placement sebagai pendukung unsur naratif.

\section{Product Placement dalam Film "Transporter 3"}

Analisis kemunculan dimensi product placement akan ditinjau secara keseluruhan pada scene film "Transporter 3" yang memunculkan product placement. Perolehan data hasil observasi didapat dari tahap sebelumnya. Penjelasan akan dipermudah menggunakan tabel scene dan membaginya ke dalam dimensi product placement sebagai berikut:

Tabel 1 Pembagian Dimensi Product Placement

\begin{tabular}{|c|c|c|c|c|}
\hline \multirow[t]{2}{*}{ No } & \multirow[t]{2}{*}{ Scene } & \multirow[t]{2}{*}{ Produk } & \multicolumn{2}{|c|}{$\begin{array}{l}\text { Dimensi Product } \\
\text { Placement }\end{array}$} \\
\hline & & & Visual & Audio \\
\hline 1. & EXT. JALAN KELUAR KAPAL - DAY & & $\checkmark$ & \\
\hline 2. & EXT. POS PENJAGA 1 - DAY & & $\checkmark$ & \\
\hline 3. & $\begin{array}{l}\text { EXT. SKOCI KECIL PINGGIR LAUT } \\
\text { - DAY }\end{array}$ & $\begin{array}{c}\text { Mobil } \\
\text { Audi A8 L }\end{array}$ & & $\checkmark$ \\
\hline 4. & EXT. POS PENJAGA 2 - DAY & & $\checkmark$ & \\
\hline 5. & EXT. JALAN KOTA 1 - DAY & & $\checkmark$ & \\
\hline
\end{tabular}


Setelah melakukan observasi secara keseluruhan pada objek, product placement ditemukan muncul dalam 36 scene. Pembagian dimensi product placement berdasarkan teori yang disebutkan dalam bab landasan teori dari Russel. Film "Transporter 3" menggunakan dimensi visual product placement sebanyak 34 scene dari keseluruhan 36 scene. Sisanya 2 scene menggunakan dimensi auditory berupa dialog yang disebutkan oleh tokoh Tarconi. Terdapat 4 produk dalam film berupa logo, kemasan dan juga merek yaitu, Audi (seri A8 L W-12), Mercedes-Benz (seri E-Class), Seagram's dan juga Nokia (seri 8800 Sirocco). Kemunculan product placement didominasi oleh produk mobil Audi (seri A8 $\mathrm{L}$ W-12) yaitu muncul sebanyak 31 scene. Mobil Audi (seri A8 L W-12) muncul melalui dimensi visual sebanyak 30 scene dan 1 scene melalui dimensi auditory. Merek mobil Mercedes muncul menggunakan 3 scene yaitu, dimensi visual 2 scene dan 1 scene dimensi auditory. Produk ketiga adalah munculnya sebuah produk minuman vodka dengan merek Seagram's, menggunakan 1 scene dimensi visual. Terakhir handphone merek Nokia juga muncul hanya 1 scene secara visual.

\section{Analisis Product Placement Terhadap}

\section{Unsur Naratif}

1. Product placement mobil Audi (Tabulasi jumlah Scene)

a. Tabulasi product placement

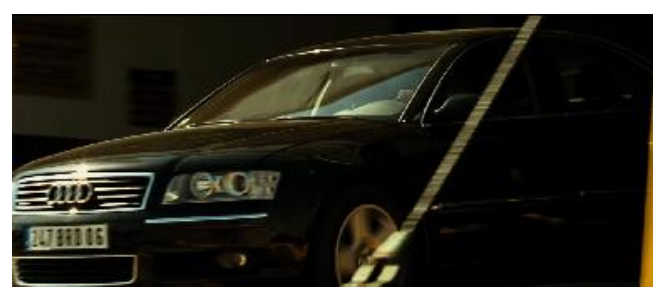

Gambar Screenshot logo Audi di scene 5

Produk pertama yang muncul dalam film "Transporter 3" adalah mobil Audi. Keseluruhan 36 scene product placement, mobil Audi mendominasi dengan muncul sebanyak 31 scene. Muncul pertama kali pada scene 5 , dengan 2 shot berdurasi kurang lebih 10 detik. Pada shot 1 muncul logo dengan jelas dibagian mobil depan, terlihat dari sudut pandang depan bagian kiri mobil. Muncul di shot 2 logo dari sudut pandang bagian belakang. Adegan dalam scene 5 adalah tokoh Malcom mengendarai mobil Audi membawa penumpang seorang puteri menteri (Valentina), keluar dari kapal besar dan melewati pemeriksaan petugas keamanan pertama pelabuhan.

b. Analisis product placement mobil Audi terhadap unsur naratif

Gambar diatas adalah contoh shot pada scene 5, kemunculan logo mobil Audi dalam mendukung penjelasan latar tempat film berada di negara Eropa, karena mobil Audi merupakan produk Eropa yaitu negara Jerman. Namun belum terlihat jelas di negara mana, hanya 
sebagai informasi film bukan berlokasi di Asia. Kemudian shot selanjutnya diperlihatkan sebuah kapal besar dengan tulisan "Monte Cinto - Marseille" sedang berada di pelabuhan. "Marseille" adalah kota di negara Perancis, merupakan kota terbesar kedua setelah Paris. Pengenalan lokasi di awal cerita menjadi jelas yaitu berada di Eropa tepatnya Perancis.

Penjelasan peran tokoh Frank didukung dengan kehadiran logo mobil Audi pada scene 27, yaitu sebagai penggerak cerita dalam film. Sebagai penggerak cerita karena, dalam cerita Frank berprofesi menjadi kurir dan otomatis mobil adalah alat vitalnya dalam menyelesaikan pekerjaan. Kemudian dalam adegan tokoh Johnson memasang gelang detonator di tangan Frank, bom akan meledak saat Frank jauh $75 \mathrm{ft}$ dari mobil. Logo muncul dari bagian depan mobil dan nampak jelas di bagian tengah frame, sehingga menjadi point of interest saat para penonton melihat.

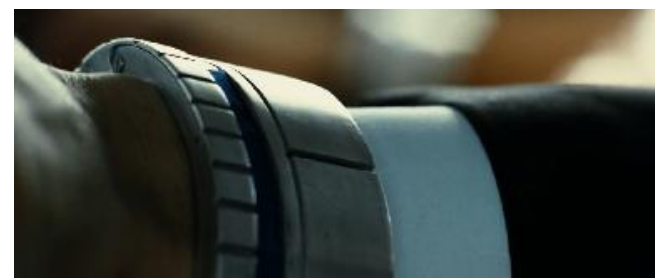

Gambar Screenshot logo Audi di scene 27
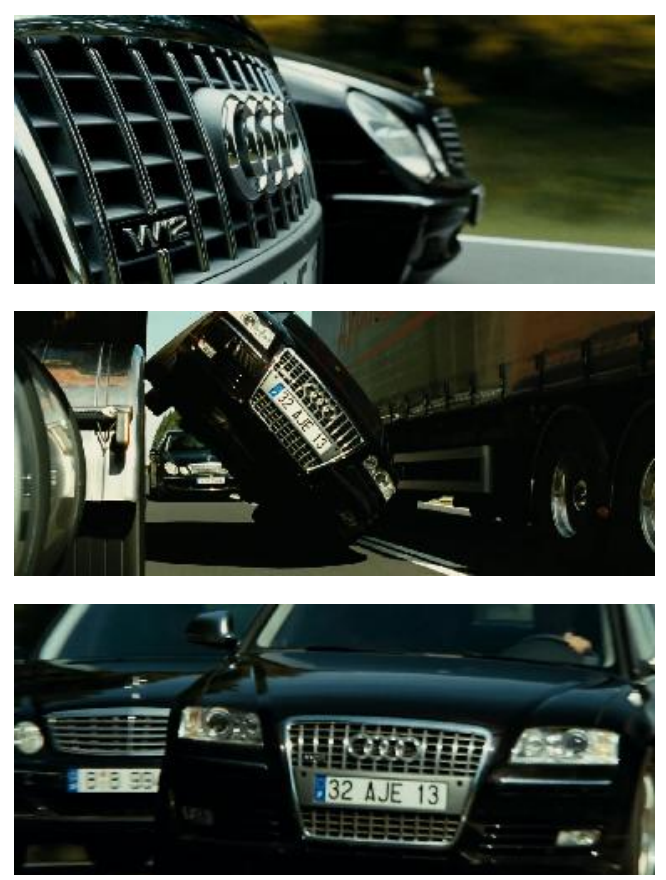

Gambar Screenshot logo Audi di scene 73

Pemanfaatan logo terletak pada tengah frame dan berukuran besar sangat bagus dalam menjelaskan pemilik mobil adalah tokoh yang mempunyai watak tegas tangguh dan berani. Seperti 3 dimensi tokoh Frank yaitu seorang pria dewasa dengan penampilan gagah berani perawakan tegap, sifat perfeksionis, bertanggungjawab, tidak menyukai keterlambatan. Didukung juga dengan warna hitam mengkilap bersih dari mobil Audi, menggambarkan Frank adalah seorang pribadi yang dingin, kritis, kaku, tidak ramah, dan ekspresi datar.

Adegan dalam scene 73 adalah konflik antara Frank dan anak buah menteri dengan ditunjukkan aksi kejar-kejaran. Pada scene 73 juga diperlihatkan aksi dari Frank dan keahlian 
kemudinya. Mulai dari tarikan gas dan kegesitan dalam mengendarai mobil sampai atraksi mobilnya berjalan dengan kondisi body mobil miring melewati sela 2 truk besar.

Adegan balapan mobil Audi dengan Mercedes menunjukkan perbedaan kemampuan antara keduanya. Seperti dalam cerita, akhirnya Frank memimpin aksi kejar-kejaran dari anak buah menteri. Terbukti kecepatan maksimum dari mobil Audi A8 L W-12 sebesar $250 \mathrm{kmph}$ sedangkan Mercedes-Benz E Class E320 hanya 240kmph. Tenaga yang dimiliki mobil Audi juga besar sehingga bisa melakukan laju cepat gesit dan juga atraksi lainnya. Kemampuan yang dimiliki dari mobil Audi menjadi pendukung terjadinya konflik tokoh utama sebagai properti fungsional dalam ceritanya.

Pengambilan gambar dalam adegan juga singkat namun banyak menampilkan shot. Dalam scene 73, product placement mobil Audi muncul sebanyak 8 shot dengan durasi singkat-singkat. Dukungan shot product placement logo mobil dalam menjelaskan konflik juga terlihat beberapa kali seperti pada contoh diatas.
Menunjukkan 2 mobil yang sedang beradu kecepatan dan keahlian, namun logo mobil Audi selalu menonjol dan letaknya lebih depan dari mobil lainnya. Sempat ditunjukkan juga pengambilan gambar dengan rack focus untuk latar depan logo mobil Audi (infocus) pada shot kedua. Rack focus adalah shot yang memindahkan tampilan fokus latar depan atau latar belakang saja. Teknik rack focus digunakan untuk mengubah penekanan pada adegan kejar-kejaran antara mobil Audi dengan mobil Mercedes.

\section{Product placement mobil Mercedes}

a. Tabulasi product placement Selain mobil Audi, muncul juga merek mobil lain yaitu MercedesBenz. Kemunculan product placement mobil Mercedes dalam film “Transporter 3" melalui 3 scene saja, yaitu pada scene 61, 69, dan 72. Mobil Mercedes digunakan sebagai properti oleh tokoh anak buah menteri. Dikendarai oleh 3 orang pria, namun akhirnya jatuh ke jurang karena pertarungan dengan tokoh Frank dengan mobil Audi-nya. Pertama logo mobil Audi nampak jelas saat di scene 61, yaitu ketika tokoh Tarconi menyebutnya saat berdialog 
melalui telepon dengan Frank.

Kemudian kedua kalinya muncul

pada scene 69, sebelum konflik

terjadi dengan Frank. Terakhir pada scene 73 saat konflik dengan Frank terjadi dengan aksi kejar-kejaran mobil. Penjelasan untuk lainnya dibuatlah tabel sebagai berikut:

Tabel 4. 5 Produk Mobil Mercedes-Benz dalam Film "Transporter 3"

\begin{tabular}{|c|c|c|c|}
\hline No & Scene & Unsur Naratif & Keterangan \\
\hline & $\begin{array}{l}61 . \text { INT. } \\
\text { JALANAN } \\
(\text { MOBIL } \\
\text { TARCONI) - } \\
\text { DAY }\end{array}$ & $\begin{array}{l}\text { Plot } \\
\text { Mercedes disebut } \\
\text { dalam dialog Tarconi } \\
\text { "There is a black } \\
\text { Mercedes with some } \\
\text { Budapest probably not } \\
\text { your cheap driver's } \\
\text { friend of furious", } \\
\text { menjadi kausalitas } \\
\text { plot karena berkaitan } \\
\text { dengan adegan scene } \\
73 \text { kejar-kejaran } \\
\text { antara mobil Frank } \\
\text { dan juga Mercedes. }\end{array}$ & $\begin{array}{l}\text { Scene } 61 \text { menceritakan saat } \\
\text { Tarconi berkomunikasi } \\
\text { melalui telepon dengan } \\
\text { Frank, setelah membahas } \\
\text { masalah yang dihadapi } \\
\text { Frank, Tarconi memberitahu } \\
\text { ada sebuah mobil Mercedes } \\
\text { juga mengikuti perjalanan } \\
\text { Frank dari pihak lain. }\end{array}$ \\
\hline 2. & $\begin{array}{l}\text { 69. EXT. } \\
\text { JALAN DEKAT } \\
\text { POM BENSIN - } \\
\text { DAY }\end{array}$ & $\begin{array}{l}\text { Konflik } \\
\text { Pada scene 70, logo } \\
\text { Mercedes muncul } \\
\text { ketika Frank sedang } \\
\text { mengisi ulang bensin } \\
\text { di pom bensin. } \\
\text { Adanya mobil } \\
\text { Mercedes berfungsi } \\
\text { memperkenalkan } \\
\text { kemunculan sub- } \\
\text { konflik antara Frank } \\
\text { dan } 3 \text { orang yang } \\
\text { berada didalam mobil. }\end{array}$ & $\begin{array}{l}\text { Scene } 70 \text { menceritakan } \\
\text { ketika Frank sedang mengisi } \\
\text { ulang bensin di pom bensin } \\
\text { ada sebuah mobil Mercedes } \\
\text { berhenti dipinggir jalan } \\
\text { dekat dengan pom. Mobil } \\
\text { Mercedes ditumpangi oleh } 3 \\
\text { orang bertujuan untuk } \\
\text { mengikuti Frank dan } \\
\text { merebut Valentina. Mobil } \\
\text { diambil dari sudut pandang } \\
\text { mata Frank sehingga }\end{array}$ \\
\hline
\end{tabular}




\begin{tabular}{|c|c|c|c|}
\hline No & Scene & Unsur Naratif & Keterangan \\
\hline & & $\begin{array}{l}\text { Kemudian akhirnya } \\
\text { menjadi konflik pada } \\
\text { scene selanjutnya, } \\
\text { yaitu adegan kejar- } \\
\text { kejaran mobil yang } \\
\text { beradu kegesitan dan } \\
\text { kecepatan mobil } \\
\text { masing-masing. }\end{array}$ & $\begin{array}{l}\text { nampak dari bagian } \\
\text { belakang body mobil. }\end{array}$ \\
\hline 3. & $\begin{array}{l}\text { 72. EXT. } \\
\text { JALANAN BALAP } \\
\text { MOBIL - DAY }\end{array}$ & $\begin{array}{l}\underline{\text { Konfik }} \\
\text { Konfik dalam scene } \\
73 \text { ini sedang } \\
\text { dijalankan, sehingga } \\
\text { kedua mobil akan } \\
\text { mendukung sekali } \\
\text { konflik yang sedang } \\
\text { berjalan. }\end{array}$ & $\begin{array}{l}\text { Scene } 74 \text { menceritakan } \\
\text { adegan kejar-kejaran antara } \\
\text { mobil Frank dan juga } \\
\text { pengemudi Mercedes. }\end{array}$ \\
\hline
\end{tabular}

c. Analisis product placement mobil Mercedes-Benz terhadap unsur naratif

Mobil Mercedes Benz EClass cocok digunakan oleh tokohtokoh pendukung yaitu anak buah menteri karena dalam adegan juga ditunjukkan kemampuan dari Mercedes Benz E-Class yang diadukan kecepatan dengan Audi A8 $\mathrm{L} \quad \mathrm{W}-12$. Perbandingan Mercedes mempunyai kecepatan 240 kmph sedangkan Audi maksimum kecepatan $250 \mathrm{kmph}$, bisa di logika jika kedua mobil diadukan kecepatan laju hasilnya akan lebih dulu Audi. Namun berbeda lagi jika yang digunakan ketiga anak buah Menteri merupakan mobil Mercedes-Benz S-Class, karena kecepatan dan kecanggihannya sebanding dengan Audi Seri A8 L W-12.

Pengambilan shot untuk logo Mercedes juga tidak banyak seperti mobil Audi saat adegan balapan pada scene 72. Adegannya adalah saat kedua mobil melakukan adu kecepatan untuk berebut Valentina. Logo hanya muncul 3 kali dengan durasi total shot-nya sekitar 15 
detik dan muncul dengan jelas ditengah konflik antara dua pihak.

3. Product placement vodka Seagram's

a. Tabulasi product placement

Produk ketiga adalah minuman vodka bermerek Seagram's, muncul pada scene 68 melalui dimensi visual. Minuman vodka sebagai properti diambil dari rak toko didekat pom bensin oleh tokoh Valentina. Adegannya adalah ketika Frank sedang berhenti di pom bensin, Valentina keluar mobil dan ingin buang air kecil ke toilet terdekat.

Valentina menuju toilet di toko dekat pom bensin, namun sebelum masuk menyempatkan terlebih dahulu untuk mengambil dan mencicipi beberapa snack dan minuman di rak. Saat adegan meminum, shot tersebut dengan jelas nampak kemasan dari botol vodka Seagrams. Kemasan muncul dengan komposisi gambar ditengah frame dengan ukuran proporsi sehingga tidak akan luput dari pandangan.

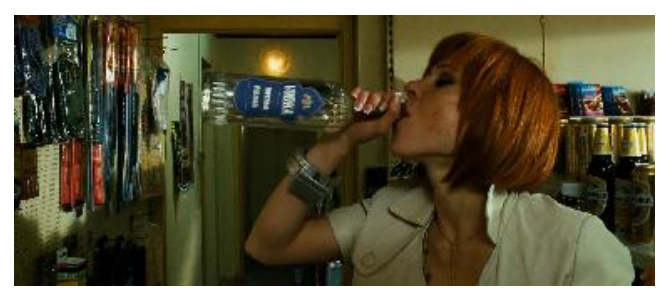

Gambar Screenshot kemasan Seagram's di scene 69 b. Analisis product placement vodka Seagram's terhadap unsur naratif

Kemunculan kemasan vodka merek Segrams mendukung plot dalam cerita karena minuman Seagrams adalah minuman jenis alkohol yang bisa membuat pikiran seseorang kehilangan kesadaran sekian persen seperti plot selanjutnya yang menceritakan aksi dari Valentina saat sedang meracau kepada Frank. Kandungan alkohol yang hanya $40 \%$ disetiap botol tidak membuat peminumnya langsung mabuk dan hilang kesadaran seketika.

Pengambilan gambar saat adegan tokoh Valentina meminum pun juga sangat strategis. Komposisi gambar kemasan berada ditengah frame, warna dari gambar kemasan juga berbeda dari warnawarna disekitar sehingga menjadi titik fokus bagi yang melihatnya.

4. Analisis product placement pada handphone Nokia

a. Tabulasi product placement

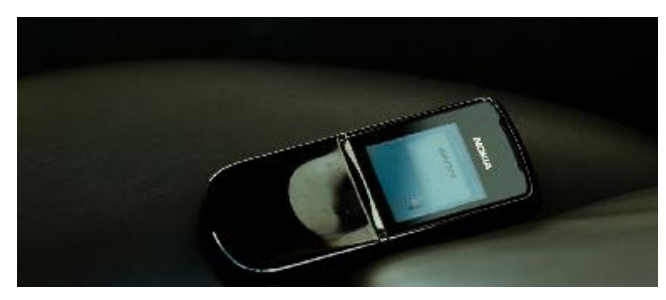

Gambar Screenshot logo Mercedes di scene 82 
Merek Nokia muncul 1 shot dalam 1 scene, yaitu scene 82. Durasi sekitar 10 detik. Pada scene 82 memvisualisaikan sebuah handphone Frank yang diberi oleh Johnson untuk berkomunikasi berdering adanya panggilan telepon dari Johnson. Panggilan mendesak dari Johnson karena koneksi lokasi Frank di maps sempat hilang setelah tragedi kejar-kejaran dengan pihak lain dan berakhir di jurang. Namun pada scene ini Frank tidak menjawab panggilan telepon karena sedang melakukan aktivitas lain yang menyita konsentrasinya.

b. Analisis product placement Nokia terhadap unsur naratif

Munculnya merek Nokia pada film "Transporter 3" mendukung latar waktu film yaitu sekitar 20072008, karena Nokia model 8800 Sirocco pertama kali lahir pada tahun 2006, sehingga masih sangat booming sekitar satu tahun atau dua tahun peluncurannya. Selain mendukung latar waktu, Nokia juga mendukung penekanan status sosial tokoh yang memilikinya yaitu seorang dari kalangan atas dan berkelas premium.

Pengambilan gambar close-up menjadikan fokus pandang tertuju pada sebuah handphone dengan jelas bermerek Nokia juga. Durasi 5 detik mendukung informasi juga siapa penelpon dalam cerita sehingga penonton juga tau alur selanjutny saat Frank dicari oleh Johnson.

Setelah melakukan analisis per produk dalam film "Transporter 3", terdapat fungsi sebagai pendukung unsur naratif dalam scene, diantaranya:

1. Plot

Kehadiran product placement dapat mendukung informasi awal pengenalan cerita seperti adegan Malcom di awal cerita, penggambaran klimaks cerita seperti adegan Frank saat mampir ke bengkel temannya, dan juga akhir cerita seperti adegan Johnson yang berakhir dengan ledakan bom ditangannya.

2. Tokoh

Melalui product placement beberapa scene dapat mendukung perkenalan, dan penggambaran 3 dimensi dari tokoh dalam cerita film “Transporter 3". Selain itu, product placement juga memperjelas peran tokoh yang diperankan dalam cerita. Maksud dari peran dalam cerita adalah tokoh utama menjadi tokoh penggerak cerita karena menggunakan salah satu produk yang sangat melekat pada cerita. 
3. Latar

Munculnya product placement pada awal scene, seperti pada scene 5 dan 6 mendukung informasi bahwa latar tempat atau lokasi dari cerita film adalah negara-negara di Eropa, karena mobil Audi merupakan produk Eropa yaitu Jerman. Selain menjelaskan latar tempat, pada scene 83 product placement juga mendukung informasi latar waktu cerita film "Transporter 3" 2007-2008.

4. Konflik

Melalui product placement dalam beberapa scene mendukung kemunculan konflik yang akan dihadapi tokoh dalam cerita. Selain itu konflik sebelumnya juga dihadirkan sehingga penonton bisa menghubungkan sendiri dengan cerita sekarang. Penjelasan konflik batin yang dialami tokoh juga bisa dibantu dengan adegan yang memunculkan juga product placement, seperti saat Frank mulai frustasi saat ingin berbincang dengan Valentina kemudian tiba-tiba mobil dihentikan secara mendadak.

\section{Penutup}

Kesimpulan hasil penelitian mengenai products placement sebagai pendukung unsur naratif film "Transporter 3" diantaranya:
1. Kehadiran products placement dalam film "Transporter 3" sebagai properti fungsional yang digunakan oleh tokohtokoh dalam film. Didominasi dengan dimensi visual yaitu sebanyak 34 scene dan sisanya 2 scene melalui dimensi auditory.

2. Kehadiran products placement muncul mempunyai fungsi sebagai pendukung unsur naratif. Meskipun begitu tidak semua products placement mempunyai fungsi sebagai pendukung setiap unsur naratif. Berdasarkan hasil penelitian, kehadiran producst placement mendukung unsur naratif diantaranya:

a. Plot

Mendukung informasi awal pengenalan, penggambaran klimaks dan akhir cerita, hal ini dapat dilihat dalam scene 7, 27, 28, 49, 83, 120, dan 137.

b. Tokoh

Mendukung perkenalan, penggambaran 3 dimensi dari tokoh, dan memperjelas peran tokoh yang diperankan dalam cerita. Hal ini dapat dilihat dalam scene 5, 6, 8, 11, 12, 13, 27, 38, 67, dan 102.

c. Konflik

Mendukung kemunculan, penjelasan dan mengerucutkan konflik yang akan dihadapi dan dialami tokoh baik nyata maupun batin. Hal ini dapat dilihat dalam 
scene $7,50,53,57,73,78,114,116$, 128, 129, 131, 135, dan 136.

d. Latar

Mendukung informasi bahwa latar tempat atau lokasi dari cerita film adalah negara-negara di Eropa dan juga informasi latar waktu cerita film "Transporter 3" yaitu tahun 2007 atau 2008. Hal ini dapat dilihat dalam scene 5, 6 dan 83.

3. Unsur naratif yang paling banyak didukung oleh adanya product placement dalam film "Transporter 3" adalah konflik. Produk selalu muncul dalam setiap adegan konflik, meskipun hanya sebagai properti tapi memang mendukung kejadian konflik.

\section{Daftar Pustaka}

Avery, Rosemary J dan Rosellina Ferraro. "Verisimilitude or Advertising? Brand Appearances on Prime Time Television." Journal of Consumer Affairs. 2000.

Biran, Misbach Yusa. Teknik Menulis Skenario Film Cerita. Jakarta: PT Dunia Pustaka Jaya. 2007.

Bordwell, David dan Thompson Kristin. Film art: an Introduction: University of Wisconsin. 2004.

Eko Santoso, Tata Artistik, Jakarta: Direktorat Pembinaan Sekolah Menengah Kejuruan. 2008.

Eriyanto. Analisis Naratif: Dasar-dasar dan Penerapannya dalam Analisis Teks Berita Media. Jakarta: Kencana. 2013.
Groote, David dalam Eko Santosa dkk. Seni Teater Jilid 1. Departemen Pendidikan Nasional, Jakarta. 2008.

Harymawan, RMA, Dramaturgi, Bandung: CV Rosda. 1988.

Himawan, Pratista. Memahami Film. Yogyakarta: Homerian Pustaka. 2008.

Lehu, Jean Marc. 2007. Branded Entertainment: Product Placement \& Brand Strategy in the Entertainment Business. London and Philadelphia: Kogan Page

Lutters, Elizabeth. Kunci Menulis Skenario, Jakarta: Grasindo. 2010.

Miles, Matthew B dan A. Michael Hubberman. Analisis Data Kualitatif. Jakarta: UI-PRESS. 1992.

Nurgiyantoro, Burhan. Pengkajian Fiksi. Yogyakarta: Gajah Mada University Press. 2002.

Russell, Cristel Antonia. "Towards Framework of Product Placement: Theoretical Propositions." Journal of Advances in Consumer Research. Vol 25 ed. Joseph W Alba and Wasley Hutchison Provo, UT: Association of Consumer Research.

Sarumpaet, Riris . Istilah Drama dan Teater. Jakarta: FSUI. 1997.

Seger, Linda. Making a Good Script Great. New York: Samuel French Trade. 1987. 
Sugiyono. Metodologi Penelitian Kuantitatif, Kualitatif dan $R \& D$. Bandung: Penerbit Alfabeta, 2017.

Sukmadinata. Metode Penelitian Pendidikan. Bandung: Rosdakarya. 2006.

\section{Pustaka Laman}

https://www.imdb.com/title/tt1129442/m ediaviewer/rm94409728

(diakses pada 18 Desember 2018 pukul 19.38 WIB)

https://sinopsisfilmbioskop21.wordpress. com/2017/03/29/sinopsis-transporter-3/ (diakses pada 18 Desember 2018 pukul 22.01 WIB)

www.acrwebsite.org/volumes/8178/volu mes/v25/NA-25

(diakses pada 20 Desember 2018 pukul 08.56 WIB)

http://www.europacorp.com/corporate/ (diakses pada 20 Februari 2019 pukul 16.27 WIB)

https://otomotifnet.gridoto.com (diakses pada 24 April 2019 pukul 23.10 WIB)

https://oto.detik.com (diakses pada 24 April 2019 pukul 23.35 WIB) 
